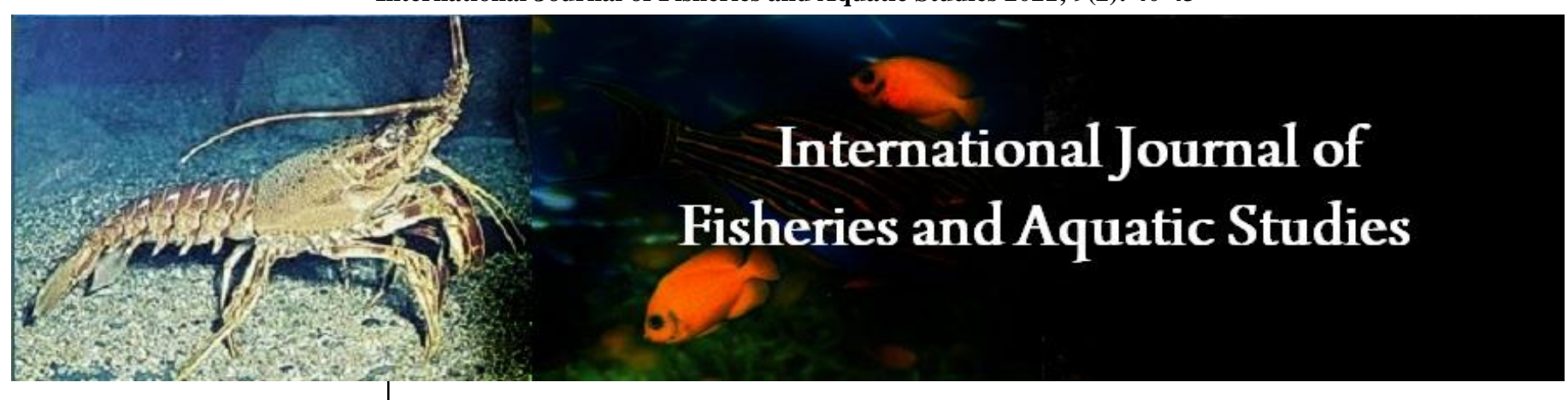

E-ISSN: 2347-5129

P-ISSN: 2394-0506

(ICV-Poland) Impact Value: 5.62

(GIF) Impact Factor: 0.549

IJFAS 2021; 9(2): 40-43

(C) 2021 IJFAS

www.fisheriesjournal.com

Received: 19-01-2021

Accepted: 21-02-2021

Ranju Kafle

Institute of Agriculture and

Animal Science (IAAS),

Tribhuvan University, Nepal

Arbind Kumar Singh

Institute of Agriculture and

Animal Science (IAAS),

Tribhuvan University, Nepal

Chaudhary Nagendra Ray Yadav Institute of Agriculture and Animal Science (IAAS),

Tribhuvan University, Nepal

Mohammad Saddam Hussain

Fisheries Research Unit,

Regional Agricultural Research

Station (RARS), Parwanipur,

Bara, Nepal
Corresponding Author: Ranju Kafle

Institute of Agriculture and

Animal Science (IAAS),

Tribhuvan University, Nepal

\section{Evaluation of different types of feed in carp polyculture}

\section{Ranju Kafle, Arbind Kumar Singh, Chaudhary Nagendra Ray Yadav and Mohammad Saddam Hussain}

DOI: https://doi.org/10.22271/fish.2021.v9.i2a.2439

\begin{abstract}
An experiment was conducted to assess the effects of different types of feed on the growth and production of common carp (Cyprinus carpio), grass carp (Ctenopharyngodon idella), and rohu (Labeo rohita) for 6 months in 9 ponds of $150 \mathrm{~m}^{2}$ each. They were fed on mash feed (T1), sinking pellet (T2), and floating pellet (T3) @ 5\% of total body weight daily along with finely chopped Dubo grass (Cynodon dactylon) for grass carp. Combined extrapolated gross and net fish yield was found the highest in T3, intermediate in $\mathrm{T} 2$, and lowest in $\mathrm{T} 1$. The feed conversion ratio was found the least in T3 followed by $\mathrm{T} 2$ and $\mathrm{T} 1$. Total production costs involved in fish production were found the highest in $\mathrm{T} 3$ followed by $\mathrm{T} 2$ and T1. The gross margin was significantly higher in T2 and T3 than in T1 $(p<0.05)$. The Benefit-cost ratio was highest in T3 but not significantly different from T2 and was found lowest in T1 $(p<0.05)$. This result showed that both sinking and floating pellet enhance nutrient utilization and higher production compared to mash feed.
\end{abstract}

Keywords: polyculture, productivity assessment, floating pellet, sinking pellet

\section{Introduction}

Polyculture is the practice of culturing more than one species of aquatic organisms in the same pond. Combinations of three Chinese carps: bighead carp (Hypophthalmichthys nobilis), silver carp (Hypophthalmichthys molitrix), and grass carp (Ctenopharyngodon idella), and the common carp (Cyprinus carpio), are most common in polyculture. The introduction of polyculture of common, Chinese, and indigenous carps into the hot lowlands has played an increasing role in Nepal's total agricultural production (Katz, 1987) ${ }^{[7]}$.

Fish feed alone consists of $60 \%$ of production cost and the protein component is the most expensive in overall feed cost (Yang et al., 2003; Erondu et al., 2006) ${ }^{[13][4]}$. Feeding the fish with suitable types of feeding practices and feed types is of prime importance in the polyculture system. Much of the mash feeds are remained uneaten by fish, which results in feed wastage and increased organic loading that eventually leads to poor water quality (Munguti, 2014) ${ }^{[8]}$. Some quantity of the supplementary feed in sinking pellet goes waste as it sinks to the bottom and fish cannot consume it but floating pellet does not have such problems (Yaqoob, 2010) ${ }^{[14]}$.

The survey conducted during the fiscal year 2015/16 revealed that most of the farmers in the Regional Agricultural Research Station command area only use mustard oil cake as a single ingredient feed in the carp polyculture production system (RARS, 2017) ${ }^{[11]}$. This production could be further enhanced by adopting different forms or types of feed. However, the best feeds available in the market have yet to be tested for their performance. This study aims to assess the growth and production performance of carp under conventional and pellet feeding systems.

\section{Materials and Methods}

\subsection{Experimental design and site}

The experiment was conducted for six months from $1^{\text {st }}$ January to $1^{\text {st }}$ July 2018 (182 days) in three earthen ponds of $500 \mathrm{~m}^{2}$ each having three partitions of $150 \mathrm{~m}^{2}$ with a nylon mosquito net to maintain 9 experimental units. The experiment was conducted in a completely randomized design (CRD) at Regional Agricultural Research Station, Parwanipur, Bara, 
Nepal. There were three treatments: mash feed (T1, control), sinking pellet (T2), and floating pellet (T3) with three replications each.

\subsection{Pond preparation}

Ponds were limed with calcium carbonate at a rate of $5 \mathrm{~kg} / 100$ $\mathrm{m}^{2}$ (Gupta and Rai, 2011) ${ }^{[5]}$ and left for one week. The entry of wild fish and exit of fish out of ponds was prevented by screening the water inlets. The water depth of $1 \mathrm{~m}$ was maintained throughout the experimental period. Research units were fertilized with inorganic fertilizers i.e. urea and Diammonium phosphate (DAP) @ $0.4 \mathrm{~g} \mathrm{~N} / \mathrm{m}^{2} /$ day and $0.1 \mathrm{~g}$ $\mathrm{P} / \mathrm{m}^{2} /$ day (Shrestha and Pandit, 2007) ${ }^{[12]}$ before a week of fish stocking and repeated biweekly.

\subsection{Stocking of fingerlings}

The stocking rates of common carp, grass carp and rohu were $67 \mathrm{fish} / 100 \mathrm{~m}^{2}$, $40 \mathrm{fish} / 100 \mathrm{~m}^{2}$ and $27 \mathrm{fish} / 100 \mathrm{~m}^{2}$, respectively. Common carp, grass carp and rohu were stocked at $1^{\text {st }}$ July 2018 in the proportions of 100:60:40 respectively in all treatments and total stocking density was maintained two hundred.

\subsection{Water quality parameters}

Water quality parameters like temperature, dissolved oxygen (DO), and $\mathrm{pH}$ were measured weekly using DO meter (Orion1230) and $\mathrm{pH}$ meter (HANNA-HI-96107) respectively. Similarly, nitrite, nitrate, and ammonia were measured monthly by using Digital water testing exact Eco-Check kit \#486798-k every week. All the measurement was recorded at 6.00-7.00 am from the depth of $25 \mathrm{~cm}$.

\subsection{Fish growth measurement}

About $15 \%$ population of each fish species was captured randomly using a dragnet for monthly sampling from each experimental unit by taking individual and batch weights using an electronic balance, and these fishes were released back into their respective experimental units. Growth parameters like total weight gain $\left(\mathrm{kg} / 150 \mathrm{~m}^{2}\right)$, gross fish yield (GFY), net fish yield (NFY), daily weight gain (DWG), survival rate and feed conversion ratio (FCR) were calculated at the end of harvest.

\subsection{Economic analysis}

Economic analysis was performed to determine the benefitcost ratio $(\mathrm{B} / \mathrm{C})$ in carp polyculture. The economic analysis was based on the farm gate prices for the harvested fish and current local prices for all other inputs. The farm gate price of common carp and rohu was NRs. $250 / \mathrm{kg}$, and grass carp was NRs. 200/kg respectively. The fingerling cost was NRs 5, 1, and 2 per piece for common carp, grass carp, and rohu respectively. The costs of feed, inorganic fertilizer, lime and carp fingerlings were variable.

\subsection{Statistical analysis}

Experimental data were analyzed by using MSTAT-C (version 1.3). One-way ANOVA was performed for the test of significance at an alpha level of $0.05(P<0.05)$. Means were compared by DMRT $(P<0.05)$. Microsoft Excel computer program was used for data tabulation and figure preparation. All means were given with \pm standard error (SE).

\section{Results \& Discussion}

\subsection{Water quality parameter}

The average values of weekly and monthly measured water quality parameters (temperature, $\mathrm{DO}, \mathrm{pH}$, ammonia, nitrate, and nitrite) over the experimental period are shown in Table 1. Statistical analysis showed that there was no significant difference among the treatments $(P>0.05)$ for water quality parameters. The single pond was used as three experimental units consisting of three different treatments, separated from each other by a mosquito net. This might be the reason to show non-significant differences as the movement of water took place between experimental units.

Table 1: Temperature, dissolved oxygen, $\mathrm{pH}$, ammonia, nitrite and nitrate in different treatments during the experimental period (Mean $\pm \mathrm{SE}$ )

\begin{tabular}{|c|c|c|c|}
\hline \multirow{2}{*}{ Parameters } & \multicolumn{3}{|c|}{ Treatments Mean } \\
\cline { 2 - 4 } & T1 & T2 & T3 \\
\hline Temperature $\left({ }^{\circ} \mathrm{C}\right)$ & $22.05 \pm 0.04$ & $22.08 \pm 0.05$ & $22.12 \pm 0.05$ \\
\hline Dissolved oxygen $(\mathrm{mg} / \mathrm{L})$ & $6.32 \pm 0.13$ & $6.70 \pm 0.07$ & $6.68 \pm 0.05$ \\
\hline $\mathrm{pH}$ & $7.70 \pm 0.07$ & $7.79 \pm 0.04$ & $7.60 \pm 0.07$ \\
\hline Ammonia $(\mathrm{mg} / \mathrm{L})$ & $0.12 \pm 0.02$ & $0.11 \pm 0.02$ & $0.11 \pm 0.02$ \\
\hline Nitrite $(\mathrm{mg} / \mathrm{L})$ & $0.04 \pm 0.01$ & $0.03 \pm 0.01$ & $0.03 \pm 0.01$ \\
\hline Nitrate $(\mathrm{mg} / \mathrm{L})$ & $1.68 \pm 0.09$ & $1.58 \pm 0.09$ & $1.48 \pm 0.11$ \\
\hline
\end{tabular}

\subsection{Fish Growth Measurement}

Initial mean weight $(\mathrm{g})$, final mean weight $(\mathrm{g})$, daily weight gain (g/day) and survival (\%) of common carp and rohu were not significantly different among treatments $(P>0.05$; Table $2)$. Total weight gain of common carp was found significantly $(P<0.05)$ highest in the floating feed (T3) followed by sinking feed (T2) and mash feed (T1). Similarly, the total weight gain of rohu was found the highest in $\mathrm{T} 2$ which was significantly different from T1 and T3 $(P<0.05$; Table 2$)$ while T1 and T3 were statistically at par $(P>0.05)$. In the case of grass carp, daily weight gain and final mean weight were highest in T3 among all treatments which were significantly different from $\mathrm{T} 1(P<0.05)$, but not significantly different from $\mathrm{T} 2(P>0.05)$ and total weight gain was obtained the highest in T3 followed by $\mathrm{T} 2$ and $\mathrm{T} 1$ which were significantly different $(P<0.05$; Table 2).

Maximum total weight gain of common carp and grass carp among the treatment was found on floating feed fed ponds followed by sinking and lowest on mash feed. It was found that floating feed is better than sinking feed for increasing fish production. On the other hand, rohu showed a higher growth in sinking feed followed by floating feed and lowest in mash feed. It may be due to the feeding habit of rohu, which feeds on the column and bottom of the pond (Chondar, 1999) ${ }^{[2]}$. Rahman (2008) ${ }^{[10]}$ reported that rohu spent more time close to the bottom in tank culture in the presence of common carp, presumably to increase their consumption of zooplankton; in the process, rohu temporarily switched from being a column feeder to a bottom feeder. According to Craig et al. (2017) ${ }^{[3]}$ feeding both floating and sinking feed to fish can give satisfactory growth, but prefer to feed type depends upon species. Although common carp is a bottom feeder, they also suck in objects floating on the surface (Bauer, 2014) ${ }^{[1]}$ which may be the reason to get a higher yield of common carp in the floating feed. Common carp is a flexible and opportunistic feeder that can switch from preferred to alternative diets according to food availability (Hoole et al., 2001) ${ }^{[6]}$. 
Extrapolated gross fish yield (GFY) and net fish yield (NFY) of common carp were found significantly highest $(P<0.05$; Table 2) in T3 followed by T2 and T1. The extrapolated gross fish yield of grass carp was found the highest in T3 which was significantly different $(P<0.05)$ from T1 and T2 while T1 and T2 were statistically at par $(P>0.05)$ and extrapolated net fish yield was found the highest in $\mathrm{T} 3$ followed by $\mathrm{T} 2$ and $\mathrm{T} 1$ which were significantly different $(P<0.05$; Table 2$)$ with one another. Similarly, extrapolated gross fish yield and net fish yield of rohu were found the highest in $\mathrm{T} 2$ which were significantly different $(P<0.05)$ from $\mathrm{T} 1$ and $\mathrm{T} 3$ while $\mathrm{T} 1$ and T3 were statistically at par $(P>0.05$; Table 2$)$.

Table 2: Growth, production, and extrapolated GFY and NFY of common carp, grass carp and rohu in different treatments (Mean \pm S.E.)

\begin{tabular}{|c|c|c|c|c|c|c|c|c|c|}
\hline \multirow{3}{*}{ Parameters } & \multicolumn{9}{|c|}{ Treatments } \\
\cline { 2 - 10 } & \multicolumn{3}{|c|}{ Common Carp } & \multicolumn{3}{c|}{ Grass Carp } & \multicolumn{3}{c|}{ Rohu } \\
\cline { 2 - 10 } & T1 & T2 & T3 & T1 & T2 & T3 & T1 & T2 & T3 \\
\hline Initial mean weight (g/fish) & $12.00 \pm 0.30$ & $11.00 \pm 1.70$ & $11.09 \pm 0.97$ & $3.00 \pm 0.00$ & $2.89 \pm 0.05$ & $2.61 \pm 0.05$ & $5.00 \pm 0.95$ & $5.00 \pm 0.36$ & $5.00 \pm 0.32$ \\
\hline Final mean weight (g/fish) & $287.20 \pm 17.15$ & $349.00 \pm 9.42$ & $385.00 \pm 40.34$ & $298.29 \pm 15.92^{\mathrm{b}}$ & $386.34 \pm 53.06^{\mathrm{ab}}$ & $463.33 \pm 0.01^{\mathrm{a}}$ & $256.00 \pm 14.29$ & $277.00 \pm 23.42$ & $227.00 \pm 3.91$ \\
\hline Daily weight gain (g/fish//ay) & $1.51 \pm 0.09$ & $1.85 \pm 0.06$ & $2.05 \pm 0.23$ & $1.62 \pm 0.08^{\mathrm{b}}$ & $2.10 \pm 0.29^{\mathrm{ab}}$ & $2.53 \pm 0.12^{\mathrm{a}}$ & $1.36 \pm 0.07$ & $1.48 \pm 0.12$ & $1.21 \pm 0.02$ \\
\hline Total weight gain (kg/150 $\left.\mathrm{m}^{2}\right)$ & $13.36 \pm 1.68^{\mathrm{c}}$ & $18.59 \pm 0.39^{\mathrm{b}}$ & $24.52 \pm 0.87^{\mathrm{a}}$ & $10.41 \pm 0.36^{\mathrm{c}}$ & $14.01 \pm 1.49^{\mathrm{b}}$ & $18.26 \pm 0.49^{\mathrm{a}}$ & $7.18 \pm 0.07^{\mathrm{b}}$ & $7.97 \pm 0.33^{\mathrm{a}}$ & $6.84 \pm 0.11^{\mathrm{b}}$ \\
\hline Survival (\%) & $51.67 \pm 7.85$ & $56.67 \pm 2.90$ & $67.67 \pm 5.40$ & $50.56 \pm 5.50$ & $62.22 \pm 6.50$ & $66.67 \pm 4.80$ & $78.33 \pm 3.30$ & $75.00 \pm 5.20$ & $78.33 \pm 1.70$ \\
\hline GFY (t//ha/yr) & $1.94 \pm 0.18^{\mathrm{c}}$ & $2.64 \pm 0.05^{\mathrm{b}}$ & $3.43 \pm 0.09^{\mathrm{a}}$ & $1.41 \pm 0.04^{\mathrm{b}}$ & $1.90 \pm 0.16^{\mathrm{b}}$ & $2.46 \pm 0.05^{\mathrm{a}}$ & $1.00 \pm 0.01^{\mathrm{b}}$ & $1.06 \pm 0.03^{\mathrm{a}}$ & $0.95 \pm 0.01^{\mathrm{b}}$ \\
\hline NFY (t/ha/yr) & $1.78 \pm 0.22^{\mathrm{c}}$ & $2.48 \pm 0.05^{\mathrm{b}}$ & $3.27 \pm 0.11^{\mathrm{a}}$ & $1.39 \pm 0.05^{\mathrm{c}}$ & $1.87 \pm 0.20^{\mathrm{b}}$ & $2.44 \pm 0.07^{\mathrm{a}}$ & $0.96 \pm 0.01^{\mathrm{b}}$ & $1.07 \pm 0.04^{\mathrm{a}}$ & $0.92 \pm 0.02^{\mathrm{b}}$ \\
\hline
\end{tabular}

Mean values with different superscripts in the same row are significantly different $(P<0.05)$

Combined extrapolated NFY (t/ha/year) and GFY (t/ha/year) were significantly different among treatments $(P<0.05$; Table 3 ). Combined extrapolated net fish yield and gross fish yield was obtained the highest in T3 among all treatments which were significantly different from $\mathrm{T} 2$ followed by $\mathrm{T} 1$ $(P<0.05)$. T1 and T2 were also significantly different $(P<0.05$; Table 3).

Table 3: Combined extrapolated GFY and NFY of carps in different treatments (Mean \pm S.E.)

\begin{tabular}{|c|c|c|c|}
\hline \multirow{2}{*}{ Parameters } & \multicolumn{3}{|c|}{ Treatments } \\
\cline { 2 - 4 } & T1 & T2 & T3 \\
\hline Combined extrapolated GFY (t/ha/yr) & $4.35 \pm 0.20^{\mathrm{c}}$ & $5.59 \pm 0.10^{\mathrm{b}}$ & $6.84 \pm 0.05^{\mathrm{a}}$ \\
\hline Combined extrapolated NFY (t/ha/yr) & $4.14 \pm 0.25^{\mathrm{c}}$ & $5.43 \pm 0.15^{\mathrm{b}}$ & $6.64 \pm 0.07^{\mathrm{a}}$ \\
\hline FCR & $3.1 \pm 0.2^{\mathrm{a}}$ & $2.1 \pm 0.1^{\mathrm{b}}$ & $1.8 \pm 0.0^{\mathrm{b}}$ \\
\hline
\end{tabular}

Mean values with different superscripts in the same row are significantly different $(P<0.05)$

\subsection{Economic analysis}

The higher FCR (3.1) was observed in the mash feed (T1) followed by sinking feed (T2) and floating feed (T3) as shown in Table 4. This result reflects that there are higher wastage and low nutrient availability of the mash feed. In contrast, feeding the pellets provides a slightly better FCR, where FCR (1.8) of floating feed was better than FCR (2.1) of the sinking which is similar to the finding of Nandeesha et al. (2013) [9]. Total gross return and the total production cost were significantly higher in floating pellet followed by sinking pellet and mash feed. Although there was no significant difference between sinking and floating pellets, the best result was obtained for floating pellets, which is similar to the result obtained by Nandeesha et al. (2013) ${ }^{[9]}$. The gross margin was higher for floating pellets compared to the sinking pellet but was lowest for the mash feed. It is evident from the study that by adopting quality feed, return on investment can be improved. Total production cost was highest in floating feed followed by sinking and mash feed it may be due to its high market price.

Table 4: Economic analysis of different treatments (NRs./pond) during the experimental period

\begin{tabular}{|c|c|c|c|}
\hline \multirow{2}{*}{ Variables } & \multicolumn{3}{|c|}{ Treatments } \\
\hline & T1 & T2 & T3 \\
\hline Total gross return $\left(\mathrm{NRs} / 150 \mathrm{~m}^{2}\right)$ & $7220 \pm 459^{c}$ & $9443 \pm 216^{\mathrm{b}}$ & $11493 \pm 147^{\mathrm{a}}$ \\
\hline \multicolumn{4}{|c|}{ Variable cost $\left(\mathrm{NRs} / 150 \mathrm{~m}^{2}\right)$} \\
\hline Lime & 150 & 150 & 150 \\
\hline Feed & $3271^{\mathrm{c}}$ & $3820^{\mathrm{b}}$ & $4787^{\mathrm{a}}$ \\
\hline Urea & 252 & 252 & 252 \\
\hline DAP & 225 & 225 & 225 \\
\hline Carp fingerlings & 640 & 640 & 640 \\
\hline Total production cost $\left(\mathrm{NRs} / 150 \mathrm{~m}^{2}\right)$ & $4538 \pm 80^{c}$ & $5087 \pm 31^{\mathrm{b}}$ & $6054 \pm 7^{a}$ \\
\hline Gross margin (NRs/150m²) & $2681 \pm 500^{\mathrm{b}}$ & $4355 \pm 242^{\mathrm{a}}$ & $5439 \pm 144^{\mathrm{a}}$ \\
\hline Gross margin (NRs/ha/yr) & $358000 \pm 66968^{\mathrm{b}}$ & $582000 \pm 32474^{\mathrm{a}}$ & $727000 \pm 19369^{a}$ \\
\hline BC Ratio & $1.59 \pm 0.11^{\mathrm{b}}$ & $1.86 \pm 0.05^{\mathrm{a}}$ & $1.90 \pm 0.02^{\mathrm{a}}$ \\
\hline
\end{tabular}

Mean values with different superscripts in the same row are significantly different $(P<0.05)$.

This result suggests that artificial feed, both sinking and floating enhance nutrient utilization and better production, which is reflected in the improved percentage of total weight gain, FCR, survival percentage, extrapolated net fish yield and gross fish yield, and BC ratio in common carp, grass carp, and rohu as compared to mash feed. Though there was no significant difference between benefit-cost ratio and gross margin of common carp, grass carp, and rohu fed on sinking and floating feed, farmers may incorporate sinking feed in the diet of these carps instead of floating feed to minimize the cost of production, since the total cost of sinking feed is lower than floating feed. 


\section{Conclusion}

It was found that gross fish yield and net field yield were highest in the floating pellet. The benefit-cost ratio (B:C) ratio was also found to be highest in the floating feed but was not significantly different from sinking pellets. From this experiment, we can conclude that both floating and sinking pellets are appropriate for carp feeding.

\section{Acknowledgement}

The authors are grateful to the Institute of Agriculture and Animal Science, Nepal and Regional Agricultural Research Station, Parwanipur, Bara for providing research facilities and staff support.

\section{References}

1. Bauer D. The Carp-O-Rama Handbook: Family Fishing Events Nebraska games and parks commission, Nebraska, USA 2014.

2. Chondar SL. Biology of Finfish and Shell fish. SCSC Publishers, Howrah, India 1999, 514.

3. Craig S, Helfrich LA, Kuhn D, Schwarz MH. Understanding Fish Nutrition, Feeds, and Feeding. Virginia Cooperative Extension 2017, 420-256.

4. Erondu ES, Bekibela D, Gbulubo AT. Optimum crude protein requirement of catfish, Chrysichthys nigrodigitatus. Journal of Fisheries International 2006;1(1-2):40-43.

5. Gupta MC, Rai S. Effect of dedhuwa (Esomus danricus), mara (Amblypharyngodon mola) and pothi (Puntius sophore) on carp production in Chitwan, Nepal. Our Nature 2011;9(1):112-118.

6. Hoole D, Bucke D, Burgess P, Wellby I. Diseases of carp and other cyprinid fishes. Oxford: Fishing News Books, England 2001, 264.

7. Katz A. The role of aquaculture in Nepal: Towards sustainable development. Ambio 1987, 222-224.

8. Munguti J, Musa S, Orina PS, Kyule DN, Opiyo MA, Charo-Karisa $\mathrm{H}$ et al. An overview of current status of Kenyan fish feed industry and feed management practices, challenges and opportunities. International Journal of Fisheries and Aquatic Studies 2014;1(6):128137.

9. Nandeesha MC, Sentilkumar V, Antony JPP. Feed management of major carps in India, with special reference to practices adopted in Tamil Nadu. On-farm feeding and feed management in aquaculture. FAO Fisheries and Aquaculture Technical Paper 2013;583:433-462.

10. Rahman MM, Verdegem MC, Nagelkerke LA, Wahab MA, Verreth JA. Swimming, grazing and social behaviour of rohu Labeo rohita (Hamilton) and common carp Cyprinus carpio (L.) in tanks under fed and non-fed conditions. Applied Animal Behaviour Science 2008;113(1-3):255-264.

11. RARSP. Annual Report 2073/74(2016/17). Regional Agricultural Research Station, Parwanipur, Bara, Nepal 2017.

12. Shrestha MK, Pandit NP. A textbook of principle of aquaculture.1st edition. Department of Aquaculture, Institute of Agriculture and Animal Science, Rampur, Chitwan, Nepal 2007, 38-44.

13. Yang SD, Lin TS, Liou CH, Peng HK. Influence of dietary protein levels on growth performance, carcass composition and liver lipid classes of juvenile
Spinibarbus hollandi (Oshima). Aquaculture Research 2003;34(8):661-666.

14. Yaqoob M, Ali MR, Mehmood S. Comparison of growth performance of major and Chinese carps fed on floating and sinking pelleted supplementary feeds in ponds. Pakistan Journal of Zoology 2010;42(6):765-769. 